\title{
(Nie)pamięć na gruzach. Zagłada Żydów żółkiewskich w świadomości nowych mieszkańców miasta
}

\section{Prolog: punkt wyjścia}

Pytanie o pamięć Zagłady jest szczególnie problematyczne w miejscach, gdzie po wojnie z różnych względów zabrakło jej świadków. Miejscem takim jest Żółkiew, małe miasteczko położone obecnie na Ukrainie Zachodniej, na trasie prowadzącej ze Lwowa do granicy z Polską. Przed wojną Żółkiew leżała w województwie lwowskim Drugiej Rzeczypospolitej i była dość typowym galicyjskim miasteczkiem: jej jedenastotysięczna ludność składała się z Żydów, Polaków i Ukraińców (odpowiednio 40, 35 i 25 procent) ${ }^{1}$. W czasie wojny w Żółkwi powstało getto, w którym zgromadzono nie tylko miejscowych Żydów, lecz także Żydów z okolicznych mniejszych miejscowości². Część mieszkańców getta trafiła do obozu zagłady w Bełżcu (akcja likwidacyjna została przeprowadzona 25 listopada 1943 r.), pozostali zaś, jak w wielu innych miejscach w Galicji, zginęli podczas masowych egzekucji właściwie na oczach swoich sąsiadów. Z Zagłady ocalały w Żółkwi 74 osoby - przechowane

${ }^{1}$ Drugi powszechny spis ludności z dn. 9 XII 1931 r. Mieszkania i gospodarstwa domowe, ludność, stosunki zawodowe. Województwo lwowskie bez miasta Lwowa, „Statystyka Polski”, seria C, z. 68, Warszawa: Główny Urząd Statystyczny, 1938, s. 32-38; A. Turczyn, Administratywno-statystycznyj ohlad 1880-1979 [w:] Żowkiwszczyna. Istoryko-memuarnyj zbirnyk, t. 2, red. Jarosław Kalika, Lwiw: Instytut Ukrajinoznawstwa im. I. Krypjakewycza NAN Ukrajiny-Zemlaćke Objednannia „Żowkiwszczyna”, 1995, s. 94. Skład etniczny miasta podaję jedynie w przybliżeniu z uwagi na różnice w dostępnych źródłach, z których żadne nie jest do końca wiarygodne; nie ujmują też one najczęściej złożonej kwestii tożsamości etnicznych i narodowych, opierają się bowiem na kryteriach takich jak wyznanie czy język ojczysty. Na temat dyskusyjności danych ze spisu powszechnego w 1931 r. zob. Grzegorz Siudut, Pochodzenie wyznaniowo-narodowościowe ludności Małopolski Wschodniej i Lwowa wedle spisu ludności z 1931 r. [w:] Lwów. Miasto - społeczeństwo - kultura, t. 2, red. Henryk Żaliński, Kazimierz Karolczak, Kraków: Wydawnictwo Naukowe Wyższej Szkoły Pedagogicznej, 1998; Piotr Trojański, Liczba, rozmieszczenie oraz struktura wewnętrzna ludności wyznania mojżeszowego [w:] Lwów. Miasto - społeczeństwo - kultura, t. 4, red. Henryk Żaliński, Kazimierz Karolczak, Kraków: Wydawnictwo Naukowe Akademii Pedagogicznej, 2002.

${ }^{2}$ Getto żółkiewskie powstało w pierwszych dniach grudnia 1942 r. Miało charakter zamknięty, otoczone było drutem kolczastym. 
przez chrześcijan, ukrywające się w lasach, wywiezione na Wschód przez Sowietów. Po „wyzwoleniu” Żółkwi przez Armię Czerwoną w mieście pozostało zaledwie kilku Żydów. Pozostali ocaleni wyjechali z Żółkwi podczas powojennej „repatriacji” ludności polskiej³ . Do dziś pozostała w mieście tylko jedna rodzina otwarcie przyznająca się do tożsamości żydowskiej.

Żółkiew jako społeczność dotknęła w czasie wojny nie tylko Zagłada. Podczas pierwszej okupacji sowieckiej (1939-1941) masowym represjom poddano polska i ukraińską inteligencję. Politykę tę kontynuowano po „wyzwoleniu” Żółkwi przez Armię Czerwoną w 1944 r. W latach 1944-1946 miasto opuściła większość Polaków, którzy „dobrowolnie repatriowali się” do Polski. Władze rozpoczęły budowanie nowej, radzieckiej Żółkwi od rozprawienia się z ukraińskim ruchem partyzanckim. Do 1952 r. aresztowano, wywieziono na Syberię lub rozstrzelano kilkuset żółkiewskich Ukraińców - członków UPA, pomagających partyzantom lub tylko o to podejrzewanych. Do pustego miasta zaczęli napływać nowi osadnicy. Pierwszą grupą byli Ukraińcy deportowani z terenów wschodniej Polski: Chełmszczyzny, okolic Lubaczowa i Tomaszowa Lubelskiego. Druga grupę stanowili Ukraińcy z okolicznych wsi, którzy w poszukiwaniu lepszego bytu przenosili się do miasta. Trzecia, najmniej liczna, lecz bardzo istotna grupa to „migranci ideologiczni” - ludzie sowieccy, którzy mieli za zadanie poddać miasto sowietyzacji. Byli wśród nich żołnierze i oficerowie Armii Czerwonej (w Żółkwi stacjonował po wojnie duży garnizon wojskowy), funkcjonariusze różnych służb i członkowie aktywu partyjnego, a także nauczyciele, inżynierowie i urzędnicy z Ukrainy Wschodniej i innych republik Związku Radzieckiego ${ }^{4}$. To oni tworzyli nową żółkiewską elitę i byli głównymi beneficjentami nowej rzeczywistości.

W tej nowej społeczności pamięć Zagłady nie była rzeczą wygodną dla władz, a w powojennej atmosferze zastraszenia nieliczni przedwojenni mieszkańcy niechętnie rozmawiali z przybyszami o miejscowej historii. Żółkiew miała stać się wzorowym radzieckim miastem, z nowymi mieszkańcami, odciętymi od swoich korzeni, i z bardzo selektywnym odwoływaniem się do dotychczasowej historii miasta. Tożsamość nowej Żółkwi miała opierać się na micie odwiecznej ukraińskości tych ziem, tradycji podziemnego ruchu komunistycznego w okresie międzywojnia i przekazie o ucisku ukraińskich chłopów i robotników przez polskich panów. Nie było w niej miejsca na eksponowanie pamięci Zagłady. Nie negowano samego faktu, nie próbowano jednak uczynić z tego elementu miejskiej tożsamości - pod tym względem sytuacja nie odbiegała od ogólnoradzieckiego standardu: Holokaust nie mógł stać się w radzieckiej pamięci wydarzeniem pierwszoplanowym, ponieważ

${ }^{3}$ Szczegółowy zapis Zagłady w Żółkwi oraz lista ocalonych zob. Gerszon Taffet, Zagłada Żydów żółkiewskich, Łódź: Wydawnictwo Centralnej Żydowskiej Komisji Historycznej przy Centralnym Komitecie Żydów w Polsce, 1946. Dane dotyczące Zagłady w Żółkwi, jeśli nie zostało zaznaczone inaczej, podaję właśnie za tym opracowaniem.

${ }^{4} \mathrm{Na}$ temat sowietyzacji Ukrainy Zachodniej w latach czterdziestych zob. David R. Marples, Stalinism in Ukraine in the 1940s, New York: St. Martin's Press 1993. 
pomniejszałby wagę radzieckich ofiar wielkiej wojny ojczyźnianej ${ }^{5}$. W wypadku Żółkwi charakterystyczną dla ZSRR obojętność wobec Zagłady widać chociażby na przykładzie losów żydowskiego dziedzictwa materialnego: renesansowej synagogi, która przetrwała wojnę, potem zaś zamieniona została na magazyn soli i w ten sposób zupełnie zniszczona wewnątrz, czy też żydowskiego cmentarza, który w latach siedemdziesiątych został zrównany z ziemią i na jego miejscu utworzono bazar.

Dopiero w takim kontekście postawić można pytanie o pamięć Zagłady w Żółkwi dzisiaj. Minęło już niemal 20 lat od upadku komunizmu, radziecki dyktat ideologiczny zastąpiła polityka pamięci prowadzona przez państwo narodowe ${ }^{6}$. Pamięć o Zagładzie w dalszym ciągu nie jest elementem kluczowym w konstruowaniu tożsamości miasta, ale jej kultywowanie stało się już możliwe. Na bazarze-cmentarzu i w miejscu masowych egzekucji za miastem pojawiły się pomniki upamiętniające żółkiewskich Żydów, postawione częściowo z inicjatywy mieszkańców miasta, częściowo z inicjatywy i przy wsparciu finansowym mieszkających dziś poza Ukrainą ocalonych. Do Żółkwi przyjeżdżają liczne wycieczki Żydów z Izraela i Stanów Zjednoczonych.

W artykule chciałabym odpowiedzieć na pytanie, jak ta nowa sytuacja wpływa na kształt pamięci o Żydach w dzisiejszej Żółkwi. Interesować mnie będzie nie tyle odtworzenie trajektorii Zagłady, ile sprawdzenie, czy pamięć ta przekazana została nowym przybyszom - tym, którzy nigdy nie doświadczyli wieloetnicznej rzeczywistości przedwojennej Żółkwi. Czy ci, którzy przyjechali do Żółkwi w latach czterdziestych i pięćdziesiątych, są świadomi wielowiekowej historii żydowsko-polsko-ukraińskiego współistnienia w tym miejscu i jego tragicznego końca? Jeśli pamięć Zagłady została przekazana nowym mieszkańcom miasta, czy był to przekaz oficjalny, publiczny, czy też prywatny, sąsiedzki? Czy i co wiedzą na ten temat przedstawiciele młodszych pokoleń? ?

Materiał empiryczny będący podstawą niniejszego opracowania stanowią 84 wywiady zebrane w Żółkwi w latach 2008-2010; na potrzeby obecnego tematu wybrałam spośród nich do analizy wywiady z osobami, które przyjechały do Żółkwi

${ }^{5} \mathrm{O}$ miejscu drugiej wojny światowej w polityce historycznej ZSRR zob. Julia Kysła, Konstrujuwanija ukrajinśkoji istorycznoji pamjati w URSR wprodowż stalinskoho periodu (1930-ti-1950-ti rr.), „Miżkulturnyj diałoh”, t. 1, Kyjiw: Identycznist’, 2009; Władysław Hrynewycz, Mit wijny ta wijna mitiw, „Krytyka” (Kyjiw) 2005, nr 5 (91), s. 2-8.

${ }^{6} \mathrm{Na}$ temat polityki historycznej niepodległej Ukrainy zob. między innymi Tomasz Stryjek, Jakiej przeszłości potrzebuje przyszłość? Interpretacje dziejów narodowych w historiografii i debacie publicznej na Ukrainie 1991-2004, Warszawa: ISP PAN-Rytm, 2005; David R. Marples, Heroes and Villains. Creating National History in Contemporary Ukraine, Budapest-New York: Central European Press, 2008.

${ }^{7}$ Używając terminu „pamięć” w kontekście nowych mieszkańców Żółkwi, mam oczywiście na myśli nie pamięć biograficzną, lecz pamięć społeczną, czyli to, co Barbara Szacka nazywa - w opozycji do doświadczenia - „wiedzą o”, a Dominick LaCapra „pamięcią wtórną” (secondary memory). Ponieważ celem tego tekstu nie jest wypracowanie nowych rozwiązań terminologicznych, ze względów stylistycznych używam w nim wymiennie pojęć „pamięć/ pamiętać” oraz „wiedza/wiedzieć”. 
po 1945 r., oraz ich dziećmi i wnukami (w całym zbiorze znajdują się również wywiady z osobami mieszkającymi w Żółkwi przed 1945 r. oraz z ich rodzinami) ${ }^{8}$. Przeprowadzane były w cyklach pokoleniowych, w rodzinach - z przedstawicielami poszczególnych pokoleń, tak by można było zaobserwować nie tylko dynamikę przekształceń pamięci, lecz także poznać charakter jej przekazu. Wywiady z najstarszymi osobami nagrane zostały zgodnie z metodą wywiadu biograficznego, wywiady z osobami młodszymi były pogłębionymi wywiadami tematycznymi ${ }^{9}$.

\section{Zasłyszane: co pamiętają przesiedleńcy}

W swoim przejmującym sprawozdaniu z podróży po Ukrainie śladem „Zagłady dokonanej przy użyciu kul” francuski badacz i duchowny Patrick Desbois stwierdza, że istnieją trzy rodzaje świadków Zagłady: ci, którzy sami nic nie widzieli, ale słyszeli od świadków; ci, którzy sami widzieli; i ci, którzy pod przymusem zaangażowani zostali w sam proces mordowania ${ }^{10}$. Z kolei Rosa Lehmann, opisując w książce Symbiosis and Ambivalence. Poles and Jews in a Small Galician Town (2001) współczesną pamięć wieloetnicznego przed wojną miasteczka Jaśliska koło Sanoka, wyróżnia trzy kategorie opowieści o Holokauście: ofiar, świadków i obcych, przy czym jako obcych traktuje również następne pokolenia, w tym dzieci ofiar i świadków ${ }^{11}$. Grupa, której pamięć będę tu analizować, sytuuje się więc w tym kontekście w różnych kręgach obcości. Wśród nich kręgiem najbliższym rzeczywistości Zagłady jest ten, w którym ludzie usłyszeli opowieść o Zagładzie tuż po wojnie, od jej świadków. Poza pojedynczymi przypadkami nie było wśród najstarszego pokolenia przesiedleńców osób, które nie wiedziałyby, co spotkało Żydów. Niemniej przesiedleńcy zastali w Żółkwi zaledwie ślady istnienia społeczności żydowskiej i to, o czym mówili podczas wywiadów, opierało się w całości na przekazie, nie zaś na ich własnym doświadczeniu. Wpłynęło to znacząco na kształt

${ }^{8}$ Część z nich powstała dzięki uzyskaniu przeze mnie stypendium Centrum Badań nad Zagładą Żydów przy IFiS PAN. Indeks rozmówców, których wypowiedzi zacytowane zostały w tekście, znajduje się na końcu artykułu; wielkie litery oznaczają pokolenie (A - najstarsze, B - średnie, C - najmłodsze), skrót k - kobietę, m - mężczyznę. Narodowość wskazana została zgodnie z identyfikacją zadeklarowaną przez respondenta.

${ }^{9}$ Na temat techniki badawczej wywiadu biograficznego zob. Kaja Kaźmierska, Wywiad narracyjny - technika i pojęcie analityczne [w:] Biografia a tożsamość narodowa, red. Marek Czyżewski, Andrzej Piotrowski, Alicja Rokuszewska-Pawełek, Łódź: Katedra Socjologii Kultury Uniwersytetu Łódzkiego, 1996; Ingeborg K. Helling, Metoda badań biograficznych [w:] Metoda biograficzna w socjologii, red. Jan Włodarek, Marek Ziółkowski, Warszawa-Poznań: PWN, 1990.

${ }^{10}$ Zob. Patrick Desbois, The Holocaust by Bullets. A Priest's Journey to Uncover the Truth behind the Murder of 1.5 Million Jews, tłum. Catherine Spencer, New York: Palgrave Macmillan, 2008 (wyd. oryg. Porteur de mémoires. Sur les traces de la Shoah par balles, Paris: Michel Lafont, 2007).

${ }^{11}$ Zob. Rosa Lehmann, Symbiosis and Ambivalence. Poles and Jews in a Small Galician Town, Oxford-New York: Berghahn Books, 2001. 
ich opowieści: wydarzenia opowiedziane, a nie przeżyte, zwłaszcza te, które nie dotyczą własnej grupy, mniej zapadają w pamięć. Przesiedleńcy rzadko poruszali temat Zagłady w pierwszej, autobiograficznej części narracji; rzadko też tworzyli obszerne, zamknięte formy narracyjne, zwykle musiałam posiłkować się wieloma naprowadzającymi pytaniami. Czasami odpowiedź ograniczała się do jednego treściwego zdania: „Tu, jak ludzie opowiadają, to też z Żydami się tak rozprawiali, pozabijali, pozakopywali” (1Ak).

Zdecydowanie najbardziej szczegółową wiedzę o Zagładzie żółkiewskich Żydów mają osoby, które przed 1945 r. mieszkały niedaleko od Żółkwi, w pobliskich wsiach. O wiele częściej mówiły o okresie przedwojennym, co wynika z tego, że miały wówczas większą niż w czasie wojny swobodę poruszania się i po prostu bywały w Żółkwi, załatwiając codzienne sprawy. Mieszkając niedaleko, często widziały jednak i część tego, co działo się z żółkiewskimi Żydami w czasie wojny: transport do obozu, pracujących więźniów, uciekinierów, czasami samą egzekucję. Co ciekawe, to również w ich wypowiedziach można znaleźć treści najbardziej antysemickie, aczkolwiek wpisujące się bardziej w ideologię antysemityzmu nowoczesnego (politycznego) niż tradycyjnego (religijnego) ${ }^{12}$. Mimo wiedzy o Zagładzie niemal „z pierwszej ręki” negatywny obraz przedwojennej codzienności jest w ich relacjach znacznie bardziej plastyczny i wyraźny niż obraz Zagłady jako takiej:

Trochę [Żydów] pamiętam. Gdzie mieszkali, gdzie myśmy coś kupowali. Ja jeszcze byłam mała, ale z tatą nieraz do Żółkwi przyjeżdżałam. (A dużo tu Żydów było?). Było! Powiem tak: Żółkiew to było prawie żydowskie miasto. I powiem pani, że ja Żyda nie szanuję. Mówiłam, że ich Niemiec bił, to mało ich bił. A oni ciągle przy władzy! To się rzadko trafia, żeby Żyd gospodarzył. On tylko lubi, żeby ktoś na niego pracował i żeby on kogoś wykorzystywał. Trochę ciężko było patrzeć na to, jak ich zabijali. Ale ja na przykład w swojej duszy... Tak dzisiaj patrzę się, jak to Żydy światem rządzą. To nikt inny nie rządzi, tylko Żyd rządzi. I ta ich podstępność, ta chytrość. Milionery, miliardery, a teraz bankrutują, te banki, to wszystko Żydzi. (Ale to tutaj Niemcy zabijali Żydów, tak?). Zabijali. Ta nasza ulica, to, co teraz jest, to oni tu mieszkali, tu było ogrodzone getto. Ale oni ich tu tak nie zabijali. Oni ich... No, jamy tam wykopywali (2Ak).

Jeśli najbliższym przed wojną większym ośrodkiem miejskim była dla przybyszów z grupy „wiejskich sąsiadów” miejscowość inna niż Żółkiew, w swoich wypowiedziach często dokonywali oni porównań z sytuacją w tej właśnie miejscowości, na podstawie analogii rekonstruując w swoisty sposób to, co musiało się stać również w Żółkwi.

(A Żydzi byli tutaj w Żółkwi?). Oj, dużo, Żydów dużo było. I w Złoczowie, ojej... Jakby to tak, nie wiem, ile by ich teraz było, tych Żydów, koszmar. W zasadzie wszystkie takie, cały handel, wszystkie takie rzeczy, to było

${ }^{12}$ Rozróżnienia na antysemityzm tradycyjny i nowoczesny używam za: Antysemityzm w Polsce i na Ukrainie. Raport z badań, red. Ireneusz Krzemiński, Warszawa: Scholar, 2004. 
w żydowskich rękach. Albo Polaków, ale Polacy to więcej zajmowali się polityka, rozumie pani, a takie finanse, to wszystko byli Żydzi. Lekarze byli prawie wszyscy Żydzi, adwokaci prawie wszyscy Żydzi, i takie tam, i teraz tak samo jest. (Ale tu ich pozabijali, w Żółkwi?). No a jakże, tu wszystko było poniszczone. (A czy miejscowi opowiadali o tym, co się z Żydami tu w Żółkwi stało?). To i dzisiaj opowiadają, że zabijali Żydów, no a jakże, to wszyscy wiedzą. Tego się przecież nie ukrywa (3Am).

Oczywiście na podstawie tak niewielkiego materiału nie można wysnuwać wniosków o większym niż w innych grupach poziomie antysemityzmu wśród migrantów ekonomicznych pochodzących ze wsi. Bardziej uprawnione wydaje się zwrócenie uwagi na to, że antysemityzm w żadnej formie nie występuje w zasadzie u osób wykształconych ${ }^{13}$. Osoby takie znacznie rzadziej formułują też sądy uogólniające, odnoszące się do „typowego Żyda”, częściej w odpowiedzi na pytanie o Żydów i ich los starają się przywołać konkretny, znany sobie przypadek i dopiero na tej podstawie wyprowadzać ogólne stwierdzenia.

Było tu Żydów, było i po [wojnie], był na przykład taki Lajner ${ }^{14}$. On tu jest u nas pochowany w Żółkwi, to on, jak opowiadał historię swojego życia, jego... Na ulicy Kutuzowa mieszkała nauczycielka, nauczyciele, on matematyk i ona matematyczka, mieli tam dom. To oni, ci nauczyciele, przechowywali Żydów, żonę tego Lajnera. On coś... Jego łapali, on opowiadał - to cała historia. On, jego łapali, a on uciekał, gdzieś stąd jakoś mu się udawało, jak opowiadał. A tak był dyrektorem piekarni tutaj. (W Żółkwi?). Tak, taki porządny człowiek. I wiersze zaczął pisać, jakieś opowiadania, wspomnienia. Już tu mieszkaliśmy, my już 22 lata tu mieszkamy, to on przychodził, żebym ja mu to redagowała, po ukraińsku, wie pani? I on jeszcze tu był, i jeszcze kilku Żydów, to już zostali ci tylko, a wtedy to getto było takie (4Ak).

W obu cytowanych tu wypowiedziach pojawia się niezwykle istotny wątek powojennych rozmów z „miejscowymi”. Wydaje się, że im częstsze i bardziej intensywne były po wojnie kontakty przybyszów z osobami, które spędziły wojnę w Żółkwi, tym więcej rozmówcy ci wiedzieli o Żydach - zarówno o rzeczywistości międzywojennej, jak i Zagładzie. Jak pisze David Lowenthal, każdorazowo wspominanie zmienia dane wspomnienie i nadaje mu nowy sens, przede wszystkim

${ }^{13}$ Czyli z wykształceniem średnim. Wśród rozmówców z Żółkwi z najstarszego pokolenia nie było ani jednej osoby, która miałaby wykształcenie wyższe. Pokazuje to, jak bardzo status przesiedleńca ( $\mathrm{z}$ wyjątkiem przybyszów z Ukrainy Wschodniej i innych republik ZSRR) wiązał się z marginalizacją społeczną.

${ }^{14}$ Zygmunt Lajner był jednym z dwojga ocalonych, którzy po wojnie pozostali w Żółkwi. Brał udział jako świadek w procesach zbrodniarzy nazistowskich, pozostawił wspomnienia, zarejestrowana została również relacja wideo z jego świadectwem (Shoah Foundation Institute, nr katalogowy 40403). Jego nazwisko padało niemal zawsze w odpowiedzi na pytanie o to, czy w Żółkwi mieszkali po wojnie jacyś Żydzi. Ponieważ w tej sytuacji można go uznać za osobę publiczną, w przytaczanych cytatach odstępuję od zasady anonimowości i zachowuję jego nazwisko. 
jednak je umacnia i chroni przed zanikiem ${ }^{15}$; również wielokrotne przywoływanie cudzych wspomnień może sprawić, że staną się one tak rzeczywiste, że „prawie swoje”. Ci, którzy na pytanie o żółkiewskich Żydów odpowiadali zdawkowo lub od razu mimowolnie przechodzili do opisu losu Żydów w swoich miejscowościach rodzinnych, nie pamiętali, by po wojnie sąsiedzi lub inni rdzenni żółkwianie poruszali ten temat. Refleksję nad brakiem przekazu znajdziemy w przytoczonym dalej fragmencie relacji kobiety należącej - trochę wbrew jej początkowej deklaracji - do tych osób, które rozmawiały i w związku tym wiedzą stosunkowo dużo. W wypowiedzi tej zwraca uwagę, że narratorka dużo swobodniej czuła się, mówiąc o rzeczach, o których dowiedziała się „z pierwszej ręki” - od sąsiadów, miejscowych Ukraińców, lub od rodziny żydowskiej, która kiedyś mieszkała w jej domu i w latach dziewięćdziesiątych złożyła jej wizytę.

Bo to było getto, cała ta ulica tu w Żółkwi, to było getto, tutaj Żydy byli zagrodzeni. Tu mieszkali właśnie Żydy, tu cała ulica była żydowska. (I w tym pierwszym domu, w którym mieszkaliście, też Żydzi?). Tak! A tu na przykład wszystko było jednego Żyda: ten dom i ten dom. Kiedyś Żydy wkładali pieniądze w nieruchomości, nie oszczędzali pieniędzy. I te cztery domy, to były wszystko żydowskie domy. To ci, co tu mieszkają od dawna, to oni wiedzą, co i jak, ale teraz już mało jest starszych, już nie zostało takich, co pamiętają. A młodzi nie wiedzą. To, proszę policzyć, my tu od 1946, 47 roku, to my jesteśmy zasiedziali. A kiedyś, co myśmy wiedzieli? Nic. Kiedyś, jak myśmy tu w 1946 roku przyjechali, to byliśmy młodzi. Nic nie wiedzieliśmy. To starsi wiedzieli, a starsi poumierali, to my tylko tyle, co usłyszeliśmy od starszych. (Ale tutaj, jak pani przyjechała, to już Żydów nie było?). Nie, nie. To już byli Ruscy, a Żydy, ich za Niemców wszystkich zabrali. W Żółkwi bardzo dużo przechowało się Żydów. Są tacy ludzie... To już poumierali. Lajner był taki, żona jego się przechowała, on się przechował. Potem jeszcze na ul. Szerokiej byli tacy ludzie, co przechowywali Żydów. (Ale większość została zabita w czasie wojny, Żydów?). A jakże, a jakże! Ci tutaj mówili, że oni wyjechali do Polski. Oni byli w Polsce, ci, co z naszego domu, pouciekali do Polski. A z Polski do Izraela. „I kto został się żywy, to tak jak my uciekł”. A byli tacy, co nie mieli możliwości uciec, to... (I o tym wszystkim to pani opowiadali miejscowi, że tu Żydzi byli?). Tak, tak! To ci, co tu mieszkali, żółkiewscy ludzie, kto tu mieszkał w Żółkwi, kto się tu urodził, to oni opowiadali (5Ak).

Motyw powojennych rozmów o losie żółkiewskich Żydów pojawia się też w wypowiedzi kolejnego rozmówcy. Pokazuje ona jednocześnie ciekawą zależność: osoby, które emocjonalnie i szczegółowo pamiętały Zagładę ze swoich miejscowości rodzinnych, z reguły bardziej interesowały się wydarzeniami w Żółkwi i również mówiąc o nich, wykazywały się większą wrażliwością i empatią. Innymi słowy, ktoś, kto w innym miejscu silnie przeżył Holokaust jako świadek, łatwiej potem przyswajał wiedzę o Zagładzie w nowym miejscu zamieszkania i bardziej się nim przejmował.

${ }^{15}$ Zob. David Lowenthal, The Past is a Foreign Country, Cambridge: Cambridge University Press, 1985. 
(Gdy pan przyjechał do Żółkwi, byli tu jeszcze Żydzi?). Byli. Ale u nas w Żółkwi, tak jak popatrzeć, to jest niewielu Żydów. Ale było ich trochę. Podczas wojny, jak tu Niemiec był, to ich pozabijali. Wie pani, masowo zabijano Żydów. Jest tu u nas żydowski cmentarz, teraz znajduje się tam bazar. To tam kiedyś chowano Żydów. Ale Niemiec wielu ich stąd powywoził do obozów. Wrócę jeszcze do tego tematu, a skoro pani zaczęła temat Żydów... Mówiłem pani, że Niemiec zastrzelił tę Sarę, małą dziewczynkę, miała jakieś dwanaście lat. Ja pamiętam to jak dziś. Taka była ładna, taki miała długi warkocz. A przez Bełz, jest takie miasto Bełz... Ich zbierali w Bełzie, zwozili ich do Bełzu, w Bełzie wsadzali ich do takich wagonów, nazywali je: bydlęce, i wieźli do Bełżca, tam były obozy. I oni ich wieźli przez naszą wieś. I myśmy już wiedzieli, krowy paśliśmy, to już wiedzieliśmy, oni dokładnie o jednej godzinie wieźli. Pociąg był cztery-pięć wagonów, na przedzie wagon strażników i na końcu wagon strażników, i jakieś wagony. Wieźli tych Żydów. To oni wyrzucali, były takie małe okienka, wyłamywali te okna i widzieli nas, ludzi - wyrzucali maleńkie dzieci przez okna, z nadzieją, że się uratują. I byli u nas tacy ludzie, którzy gdzieś dwójkę dzieci zabrali. Nikt nic nie wiedział. Ale przyszedł czas, to był gdzieś koniec 1944 roku, i ktoś doniósł. I te małe dzieci też zabrali, i tego gospodarza. To ich rozstrzelali, a co zrobili z tymi dziećmi, to nie wiemy, a tych, którzy przechowywali te dzieci, bezpośrednio u nich na podwórzu Niemcy rozstrzelali. I w Żółkwi też było dużo Żydów. W Żółkwi było gdzieś 30 procent, a może i 40 procent Żydów. Jeśli do wojny mieszkało tu jakieś 15 tys. ludzi, to z tego 40 procent było Żydów, 40 procent Polaków i 20-25 procent Ukraińców. [...] To i w książkach historycznych tak piszą, że tu było tylu Żydów, oni tu mieli, widziała pani, synagogę, ogromną synagogę. Mieli specjalny cmentarz, i miejscowi mieszkańcy, kto tutaj, miałem na przykład takiego przyjaciela [imię i nazwisko], on mówił, pamiętam, o dwa lata był starszy ode mnie, mówił: „Ile u nas było Żydów!”. W tych podsieniach, tam wszędzie mieszkali Żydzi, handlowali i tak dalej (6Am).

Przy okazji tego i kolejnego fragmentu można tylko żałować, że niemożliwa do oddania w transkrypcji jest pozawerbalna warstwa wypowiedzi. Zasadnicza struktura i treść ostatniej wypowiedzi jest w zasadzie zbliżona do następnego fragmentu: pytanie o Żydów żółkiewskich wywołuje wspomnienia o pamiętanych z rodzinnej wsi transportach do Bełżca, pojawia się też motyw pomocy Żydom.

A ludzi [żydowskich] było pełno, to niech pani policzy, było sześć tysięcy Żydów w Żółkwi, tak mówią. Prawda, [imię obecnego podczas wywiadu sąsiada]? Sześć tysięcy było. (Ale jak już pan tu przyjechał, to Żydów nie było?). A gdzie! Żydzi już byli w Bełżcu... Albo tam za strzelnica, choć więcej ich w Bełżcu było. A tu ich już nie było. (Bełżec, to jak pan był jeszcze u siebie na wsi...?). To do Bełżca Żydów wozili, to nam tak śmierdziało... Nie można było nic na dworze zrobić. (Ale to ludzie wiedzieli, wszyscy naokoło, o tym, co tam jest, ten obóz?). [...] Co nie wiedzieli? Tam palenisko śmierdziało - nie można było na polu robić. Tylko ich tam nie palili, a ubranie palili. To te ubranie tak śmierdziało. Kopali tam rów, klękali na kolana. Niemcy grali na harmoniach. Chodziło chłopców dwóch czy trzech z tyłu, i pach! - w rów, pach! - w rów. Są jeszcze zdjęcia, jak to było. Do jamy ich tam zrzucili, do jamy. Ty sam jeszcze żywy, na to wszystko narzucił piachu, i wszystko. 
(A czy ktoś przechowywał Żydów?). Jak ktoś przechowywał, to była napisana w Tomaszowie taka wielka tablica, jak pół tej ściany, że kto ukrywa ruskiego jeńca, który ucieknie, i Żyda, to kara śmierci [ostatnia fraza wypowiedziana po polsku]. Zrozumiała pani, co ja powiedziałem po polsku? Kara śmierci. [...] A tu w centrum wszędzie sami Żydzi byli. I nasza ulica, Lermontowa, to wszystko Żydzi byli. Nasz dom, gdzie mama [mieszkała], to sam Żyd. (A to wszystko, co mówi pan o Żydach tutaj, to skąd pan wie, bo jak pan tu przyjechał, to już nie było Żydów?). Gdzie, w Żółkwi? Tu już było czysto! O, tu jeszcze się Żyd chował, jak idzie się do poczty, to jest takie okienko, nie? To tam się chował Żyd, i ktoś jeść mu podawał na sznureczku. I jakaś zaraza, rozumiesz, wydała. Wydała i jego Niemcy zabrali... On tam siedział (7Am).

Gdyby oba fragmenty odsłuchać, nie zaś przeczytać transkrypcję, oprócz widocznych także w samym zapisie różnic stylistycznych, wynikających głównie z poziomu wykształcenia rozmówców i związanych z tym kompetencji narracyjnych, można byłoby zauważyć również zupełnie inny ton głosu i diametralnie odmienny ładunek emocjonalny, jakim obarczone są obie wypowiedzi. Pierwszy rozmówca opowiadał w sposób dość oszczędny, a w jego opowieści nie ma żadnych sądów wartościujących. Nie sposób jednak mylnie ocenić emocji zawartych w jego głosie: żalu, smutku w pierwszych zdaniach, a gdy mówi o małej Sarze - również wzruszenia. Opowieść drugiego rozmówcy już w warstwie słownej robi wrażenie mniej emocjonalnej - obecność sformułowań typu „Żydzi byli już w Bełżcu” czy „tu już było czysto” wskazuje na to, że Zagłada nie wywołuje w nim jakichś specjalnych emocji, choć ci, którzy się do niej przyczynili, zostali jednoznacznie osądzeni (,jakaś zaraza wydała”). Również ton jego głosu jest zdecydowanie obojętny, poruszony jedynie w momencie, gdy świadek mówi o karze śmierci spotykającej tych, którzy ukrywali Żydów.

Poziom emocji (a właściwie ich zupełny brak) towarzyszących opowieści o Żydach w Żółkwi pozwala na wyróżnienie wśród relacji Ukraińców deportowanych z Polski jeszcze jednego typu relacji. Dla bardzo wielu rozmówców charakterystyczny jest brak jakiegokolwiek zainteresowania i emocjonalnego stosunku do kwestii losu Żydów z Żółkwi. Ludzie ci wiedzą - choć zazwyczaj bez żadnych szczegółów - że przed wojną istniała w mieście społeczność żydowska, wiedzą również, co się z nią stało, ale nie jest to dla nich temat ważny, wart opowieści. Bardzo często odpowiadając na pytanie dotyczące Żydów, po kilku zdaniach przechodzą w sposób niemal niezauważalny do innych wydarzeń wojennych w Żółkwi - tych, które dotyczyły losu ich własnej grupy narodowej, Ukraińców. Sens takiej postawy można by zawrzeć w stwierdzeniu: „Nas tu nie było, więc nic nie wiemy, a poza tym to nie byli nasi, więc nas to nie interesuje”.

(A czy tutaj, w Żółkwi, było dużo Żydów?). W Żółkwi? Oj, było, całe miasto było żydowskie, tak mówią. Same te... Sklepy, to wszystko było żydowskie. Tam stoi jeszcze jakaś taka ich bóżnica... I obok cerkiew nasza piękna, tam są ci, mnisi bazylianie, odprawiają. (A po wojnie zostali jacyś Żydzi tu w Żółkwi czy nie?). A to ja nie wiem. No, tu oni ich wszystkich... Kto uciekł, a kto nie uciekł, to tak samo ich wszystkich pozabijali. Co tam... Jak już Moskale, 
jak Niemcy przychodzili, a Moskale uciekali, to tam, gdzie jest rada miejska, tam wokół są takie mury... To ile oni tam ludzi... Tam nawet z boku postawili im teraz taką kapliczkę-pomnik. Ile tam tych dzieci, ludzi, nawet dzieci, dziewczynek po piętnaście lat, chłopców... Kogo tak złapali na drodze, pchali tam i to wszystko tam pomordowali (8Ak).

Zwraca przy tym uwagę, z jakim poruszeniem przedstawiane jest w cytowanym fragmencie wymordowanie przez Sowietów więźniów miejscowego więzienia w 1941 r. Choć również to wydarzenie - tragiczne, ale o ileż mniejsze w skali niż Zagłada - nastąpiło przed przybyciem rozmówczyni do Żółkwi, zostało przez nią w dużo większym stopniu zinternalizowane, uznane za część losów swojej grupy. Żółkiewscy Żydzi ewidentnie częścią tej grupy nie są.

Nieco podobne w wymowie jest to, co o Żydach mówią rozmówcy przybyli ze Wschodu, zarówno Ukraińcy, jak i Rosjanie. Bardzo charakterystyczna dla tej grupy jest następna wypowiedź, uzyskana w odpowiedzi na pytanie, czy w okresie gdy rozmówczyni przyjechała do Żółkwi, były tam jeszcze oprócz Polaków jakieś rodziny żydowskie: „A ja tam i nie wiem dokładnie. Wiem, że tych Żydów tu gdzieś wywozili, czy oni sami wyjeżdżali. Ich ścigali, tych Żydów. No, tak dokładnie to ja nie wiem” (9Ak). Tym, co uderza we wszystkich w zasadzie wywiadach, jest właśnie nie tyle brak wrażliwości, ile po prostu brak zainteresowania tym, co działo się przed wojną i podczas okupacji w Żółkwi, niezależnie w zasadzie od tego, czy przeszłość ta dotyczyła losu Ukraińców, Polaków czy Żydów. Nie oznacza to przy tym, że rozmówcy nie zetknęli się nigdy wcześniej z Żydami jako grupą etniczną czy z problemem Zagłady. Jedna z rozmówczyń, Ukrainka pochodząca z Połtawszczyzny, ukrywała nawet w czasie wojny Żydówkę. Sposób, w jaki o tym opowiedziała, znacząco różnił się jednak od podobnych partii narracyjnych w relacjach Ukraińców deportowanych z Polski, którzy również mówiąc o Żółkwi, nawiązywali do losu „swoich” Żydów.

(A mówiła pani, że tu już Żydów nie było dużo, jak pani przyjechała?). Nie, nie było. Ja znałam tylko jednego, Lajner, on był Żydem. (A wcześniej oni tu byli?). Byli, tak. Wcześniej to tu, tak mówili, było dużo Żydów. (I co z nimi?). Powyjeżdżali. Do Izraela powyjeżdżali. A Bóg ich wie, gdzie to oni pojechali. Chyba najwięcej to do Izraela. (A za Niemców tu zabijali Żydów?). Zabijali, tak. Ale ludzie gdzieś ich ukrywali. To i u nas na Donbasie byli Żydzi. I u nas była nawet lekarka, myśmy ją ukrywali. To była Walentyna, lekarka-terapeutka. I dwa lata Niemcy byli, i ona dwa lata u nas była. I Niemcy byli! [...] Ale wiem, że ona u nas była, tak żeśmy się bali, bo czasem Niemcy przychodzili, sprawdzali, to ona nocowała w piwnicy. Łóżko tam [znosiliśmy] i ona więcej tam nocowała. Była podobna do mojej siostry i ubierała się w jej ciuchy, coś robiła w ogrodzie, pieliła. Mieliśmy takie wielkie gospodarstwo... A siostra pracowała w sowchozie. Szła do pracy, a ta pieliła tu, w domu. To myśleli, że to moja siostra, Marusia. I wołali ją: „Marusia!”. A ona odpowiadała, i oni myśleli, że to siostra. I tak przeżyła. Potem jej mąż przyjechał, bardzo dziękował. I wyjechali. Jak wychodziłam za mąż, to była jeszcze u nas na weselu... (10Ak). 
Rozmówczyni nie wróciła sama do tematu Żydów z Żółkwi. Przypomnienie sobie sprawy uratowanej Żydówki nie było więc dla niej sposobem na dokonanie zgrabnego porównania, lecz na zakomunikowanie: nie wiem nic więcej o tym mieście, nie było mnie tu wtedy, to nie moja historia i nigdy mnie to nie ciekawiło, ale mogę pani opowiedzieć o czymś podobnym, a ciekawszym, co zdarzyło się mnie samej. Los żółkiewskich Żydów, choć zapewne zdaje sobie z niego sprawę, zamyka się w jej opowieści w dwóch słowach: „zabijali, tak”. Jest losem ludzi nieznanych, o których nikt jej nawet nie opowiedział, a więc anonimowych.

To właśnie z grupy nowych mieszkańców Żółkwi, którzy przyjechali ze Wschodu, pochodzą dwie osoby, które nie wiedziały, że w Żółkwi mieszkali przed wojną jacyś Żydzi, a co za tym idzie, nie znały ich późniejszego tragicznego losu. Na pytanie o to, czy wie, jaka ludność mieszkała w mieście przed wojną, rozmówczyni odpowiedziała w sposób następujący:

No, przede wszystkim mieszkała tu miejscowa ludność, Ukraińcy i Polacy.

A potem było dużo koszarów, dużo żołnierzy, to już pamiętam. A tak, potem

przede wszystkim Ukraińcy, Polacy, rzadko Rosjanie, Żydzi (11Ak).

Żydzi pojawili się w Żółkwi w przekonaniu tej rozmówczyni dopiero po wojnie - razem z przedstawicielami wszystkich innych narodowości, którzy przyjechali do miasta w ramach sowieckiej komunistycznej i internacjonalnej kolonizacji Ukrainy Zachodniej. „Kolonizatorzy” narodowości żydowskiej rzeczywiście się w Żółkwi zdarzali, wydaje mi się jednak, że fakt, iż to właśnie rozmówcy z grupy „sowietyzatorów” jako jedyni nie wiedzieli nic o Zagładzie żółkiewskich Żydów, nie jest przypadkowy. Jedną z przyczyn jest zapewne większy niż w wypadku Ukraińców z Polski i migrantów ze wsi dystans między tymi przybyszami a nieliczną pozostałą w Żółkwi po wojnie ludnością miejscową. O ile przesiedleńców miejscowi traktowali niekiedy z pogardą i rezerwą, „wschodniaków” bali się i nienawidzili jako przedstawicieli represywnego, narzuconego systemu. Przybysze ze Wschodu z kolei bali się i nie lubili miejscowych jako „banderowców” i „nacjonalistów”. Sytuacja taka nie sprzyjała wzajemnym kontaktom, a tym bardziej wymagającym pewnej dozy zaufania rozmowom o wydarzeniach wojennych ${ }^{16}$. Gdy sytuacja unormowała się na tyle, by przedstawiciele obu grup zaczęli wchodzić ze sobą w bliższe relacje, Zagłada była już wydarzeniem sprzed lat - tym bardziej nieaktualnym, że nie naszym, nie ożywianym bezpośrednią pamięcią ofiar, a więc szybko przechodzącym do kategorii kwestii tak łatwo pomijanych milczeniem, że prawie nierealnych. Drugim powodem mogła być ogólna postawa przybyszów ze Wschodu wobec kwestii narodowościowych. Wychowani w duchu sowieckiego internacjonalizmu, już na wstępie byli mniej wrażliwi na te problemy, czasami wręcz nie dostrzegając obecności przedstawicieli różnych narodowości w Żółkwi, nie przykładając wagi choćby

${ }^{16}$ Brak zaufania i przemilczanie wielu potencjalnie ważnych tematów charakteryzowały życie społeczne w całym ZSRR, nie tylko w świeżo włączonej w granice sowieckiej Ukrainy Galicji. Zob. Orlando Figes, Szepty. Życie w stalinowskiej Rosji, tłum. Władysław Jeżewski, Warszawa: Magnum, 2009. 
do tego, kto z ich kolegów w pracy jest Ukraińcem, kto Polakiem, kto Żydem. Z tych samych względów nie interesowali się wielokulturową przeszłością miasta. Sprzyjała temu powojenna polityka historyczna ZSRR, zgodnie z którą Żydzi sowieccy, którzy zginęli w czasie Zagłady, wliczani były do ogólnej liczby radzieckich ofiar wojny $^{17}$. W takim klimacie ideologicznym pozostawanie $\mathrm{w}$ niewiedzy nie było zbyt trudne.

\section{Następne pokolenia: w meandrach pamięci}

Młodsze pokolenia mieszkańców Żółkwi, niezależnie od tego, kim byli ich rodzice i dziadkowie, zaliczyć można już tylko do kategorii obcych - w najlepszym wypadku obcych zainteresowanych tematem, a więc tych, którzy zgodnie z klasyfikacją Patricka Desbois mogą być swego rodzaju świadkami pośrednimi. Ale czy moi respondenci rzeczywiście nimi są? Większość z nich zdaje sobie sprawę z tego, że w ich mieście istniała przed wojną społeczność żydowska, pamięć o niej jest jednak bardzo fragmentaryczna i niekonkretna. Czasami sprowadza się wręcz do jednego zdania: „A do wojny to połowa Żółkwi to byli Żydzi, albo nawet więcej” $(12 \mathrm{Bm})$. Co istotne, o wiele więcej niż o Zagładzie moi respondenci wiedzą o społeczności żydowskiej sprzed wojny. Jest to przede wszystkim wiedza książkowo-przewodnikowa (odsetek Żydów w ogólnej liczbie ludności, sławne postaci, architektura), czasami - wśród osób mających swoje korzenie w okolicznych wsiach - przekazywane są w rodzinie anegdoty o „swoich Żydach”. Te ostatnie nigdy jednak nie rozciągają się na Zagładę - próżno w nich szukać historii o kolegach babci czy dziadka, którzy zginęli, wywiezieni do Bełżca. Dobrą ilustracją problemu jest wypowiedź kobiety, która po obszernej opowieści o rodzinie żydowskiej kupującej u jej babci mleko o losach Żydów żółkiewskich w czasie wojny mówi bardzo ogólnie, używając wielu określeń wskazujących na jej brak swobody jako narratora (typu ,jakiś”, „gdzieś”):

(A o wymordowaniu Żydów też babcia pani opowiadała? Bo skoro tu było tylu Żydów, a teraz w zasadzie nie ma...). No, nieee, pamiętam tylko jedną opowieść, że gdzieś, gdzieś tutaj, koło Kamjanki Buzkiej, tam pewnego dnia zabili dużo Żydów. Rodzinami ich z domów zabierali i wyganiali, było tam jakieś getto i potem ich tam Niemcy zagnali. A tak to nic nie [wiem]. (A ci żółkiewscy Żydzi? Co się z nimi stało?). Nie wiem. Pewnie ich Niemcy zabili. Oni przecież mordowali, strzelali wszystkich, jak leci, Żydów, nie-Żydów, nie przebierali (13Bk).

W zacytowanym fragmencie ujawnia się - kolejny raz - nie tylko brak wiedzy, lecz także brak zainteresowania i chęci poruszania tej kwestii. Holokaust jest wiedzą bardziej problematyczną niż samo skonstatowanie faktu, że „byli Żydzi przed wojną”, tematem mniej przyjemnym do opowiadania niż historyjki i anegdoty.

${ }^{17}$ Zob. Hrynewycz, Mit wijny...; Timothy Snyder, Holocaust: ignorowana rzeczywistość, „Res Publica Nowa” 2009, nr 7, s. 140-149. Podobnie działo się także w PRL. 
Jedna z respondentek, młoda, wykształcona kobieta, działająca w lokalnej organizacji pozarządowej promującej turystykę ekologiczną i rozwój regionalny, na pytanie o społeczność żydowską w Żółkwi obszernie i barwnie opowiedziała o wkładzie Żydów w życie kulturalne i architekturę miasta w przeszłości. Natomiast zapytana o Zagładę, powiedziała: „Hmm, czy ja coś wiem o Holokauście w Żółkwi? Nie, tej historii to ja nie znam, nie wiem dokładnie, jak się to odbywało” (14Ck). Taki stan rzeczy wynikać może częściowo ze sposobu przekazywania wiedzy o Holokauście w procesie edukacji. O ile w zestawieniu z czasami sowieckimi ważne jest już to, że Zagłada w ogóle pojawia się w podręcznikach szkolnych, o tyle trudno uznać, by poświęcano jej w programie kształcenia wystarczająco dużo miejsca. W ukraińskich podręcznikach historii, mimo deklaracji o szacunku dla wieloetniczności Ukrainy teraz i w przeszłości, mniejszości (lub czasami większości) narodowe zamieszkujące kiedyś Ukrainę wspominane są dość zdawkowo, a informacje dotyczące Holokaustu przedstawia się zazwyczaj poza ukraińskim kontekstem (np. antysemityzm w Niemczech jako przyczyna Zagłady oraz obozy koncentracyjne jako środek jej realizacji), ograniczając się co najwyżej do wzmianki o masakrze w Babim Jarze pod Kijowem, w którym w czasie okupacji niemieckiej zginęło kilkadziesiąt tysięcy osób ${ }^{18}$.

Wśród respondentów z młodszego pokolenia jedynie dwie osoby opowiedziały o Zagładzie, odwołując się do losów konkretnych przedstawicieli społeczności żydowskiej. Żadna z tych opowieści nie była obszerna, niemniej ich podmiotowe podejście na tle wszystkich innych wypowiedzi sprawia, że są wyjątkowe. Obie historie związane były - co znamienne - z ratowaniem Żydów przez chrześcijan. Historia pierwsza opowiedziana została przez kobietę, której babcia przechowywała w czasie okupacji rodzinę żydowską. Rozmówczyni nie znała zbyt wielu konkretów, ale potrafiła wskazać miejsce ukrywania się Żydów i wiedziała, że po wojnie wyjechali oni z Żółkwi. Była też niewątpliwie dumna z czynu babci, choć wydaje się, że nie zdawała sobie przy tym sprawy ze skali Zagłady, znajomość tej jednej rodzinnej historii nie prowokowała jej też do żadnych głębszych refleksji na ten temat:

Świętej pamięci dziadek wsadził ich do pociągu i tak jakby pomógł im się ewakuować stąd, z Ukrainy. A gdzie pojechali potem, to już nie mogę powiedzieć. Ale fakt, że nie trafili ani w ręce faszystów, ani Rosjan. No, tak jakby się wykaraskali, a co dalej... Nie wiem (15Ck).

Druga z historii opowiedziana została przez respondenta mieszkającego obecnie w domu, w którym w czasie wojny ukrywało się 17 Żydów ${ }^{19}$. Podczas gdy

${ }^{18}$ Zob. Nancy Popson, The Ukrainian History Textbook: Introducing Children to the „Ukrainian Nation”, „Nationality Papers” 2001, t. 29, nr 2, s. 325-350; Stefan Rohdewald, Post-Soviet Remembrance of the Holocaust and National Memories of the Second World War in Russia, Ukraine and Lithuania, „Forum for Modern Language Studies” 2008, t. 44, nr 2, s. 173-184; Anatolij Podolśkyj, Ukrajinśke suspilstwo i pamjat’ pro holokost: sproba analizu dejakach aspektiw, „Holokost i suczasnist'. Studiji w Ukrajini i switi” 2009, nr 1 (5), s. 47-59.

${ }^{19} \mathrm{Na}$ podstawie pamiętnika jednej z ukrywających się w tym domu osób, Klary Schwarz, powstała w Stanach Zjednoczonych zbeletryzowana opowieść przetłumaczona również na 
poprzednia rozmówczyni przywoływała jedynie wydarzenie z życia swojej rodziny, ten rozmówca został w pewien sposób osobiście wciągnięty w trajektorię Zagłady. Gdy w latach dziewięćdziesiątych odwiedziła go grupa Żydów ze Stanów Zjednoczonych - dwoje ocalonych i ich rodziny - ze zdziwieniem dowiedział się, że rozległa piwnica znajdująca się pod jego domem służyła w czasie wojny jako schronienie dla kilkunastu osób. Nie mniejsze wrażenie od samej historii ich ocalenia zrobiła na rozmówcy reakcja gości po wejściu do schronu.

Zdziwiłem się, oczywiście. To było takie coś, że jedna z nich... Oni tu tracili przytomność, płakali. To się takie rzeczy działy, że... Pierwszy raz, wtedy jak tutaj przyjechali, to było coś strasznego. Ja nawet nie wiedziałem, że oni tak będą reagować. Jedną stąd wyciągali, pogotowie... To było tak nie... nie bardzo tak. Coś im się poprzypominało, czy co... I tak się dowiedziałem, że coś takiego tu jest. Dla nich to jest miejsce, a dla nas - piwnica jak piwnica (16Bm).

Wizyta ocalonych okazała się dla rozmówcy wydarzeniem bardzo ważnym. Jako Rosjanin z pochodzenia, którego rodzice przyjechali do Żółkwi w latach pięćdziesiątych, do tej pory nie interesował się zbytnio przeszłością Żółkwi. Osobiste zetknięcie się z ocalonymi z Zagłady sprawiło, że przeszłość ta nabrała dla niego znaczenia, stała się bardziej rzeczywista.

Czasami ogólnikowość tego, co młodsi respondenci wiedzą na temat Zagłady w Żółkwi, bliska jest zgadywaniu na głos, dedukowaniu, dopasowywaniu okruchów wiedzy ogólnej do przypadku Żółkwi, by móc odpowiedzieć na pytanie prowadzącego wywiad. W kilku sytuacjach widać było dość wyraźnie, że respondenci zastanawiali się nad tą kwestią po raz pierwszy w życiu:

Społeczność żydowska, no, być może Żydzi byli, tak z opowieści rodziców wynika w sumie. Bo jest synagoga w Żółkwi, żydowska synagoga, to znaczy, że i Żydzi są. Ale żebym ja kogoś specjalnie znała, jakiegoś Żyda... (A kiedyś tu było więcej Żydów?). No oczywiście, skoro jest taka wielka synagoga, to znaczy, że byli. Ale mówię, moi rodzice przyjechali później, a to może przed wojną, może wtedy było ich dużo, skoro taka synagoga... (A co się z nimi stało?). Myślę, że podczas wojny, gdy Niemcy tak prześladowali Żydów, to oni pewnie wszyscy zaczęli wyjeżdżać. Pewnie ukrywali się, kto gdzie mógł. Tak mi się wydaje, bo ja sama nigdy się tym nie interesowałam. Jakoś nigdy się nie zastanawiałam, czemu rzeczywiście ich dzisiaj nie ma w Żółkwi, ale myślę, że to podczas wojny. Pewnie część wymordowali, a część, kto mógł, rozjechali się (17Bk).

We fragmencie tym pojawia się bardzo charakterystyczny motyw domniemanego wyjazdu Żydów, powtarzający się w wielu wywiadach (i będący elementem

język polski: Clara Kramer, Stephen Glantz, Wojna Klary. Prawdziwa historia cudownego ocalenia $z$ Holokaustu, tłum. Anna Sak, Kraków: Znak, 2009. Oryginał dziennika (w języku polskim) znajduje się w Holocaust Memorial Museum w Waszyngtonie. Relacja wideo Klary Schwarz (obecnie Clara Kramer) zarchiwizowana została w archiwum Shoah Foundation Institute pod numerem katalogowym 37123. 
stereotypu zaradnego Żyda, który z każdej sytuacji potrafi wyjść cało). Co ciekawe, twierdzenia o tym, że znaczna część Żydów wyjechała z Żółkwi jeszcze przed wojną, znaleźć można również w wypowiedziach tych osób, które o Zagładzie wiedzą całkiem sporo z przekazów rodzinnych:

Mówili, że było tu bardzo dużo Niemców i że oni mordowali Żydów, i katowali, i znęcali się. Jest u nas bazar, to mówią, że to cmentarz żydowski. (Cmentarz? Na bazarze?). No, żydowski. Tata nawet opowiadał, że jak był jeszcze mały, to szedł przez miasto i słyszał takie, no, że ich tam zaganiali na ten bazar, żeby kopali tam sobie groby, potem ich obok porozstawiali, i od razu rozstrzelali. No, jakoś tak. (To znaczy, że tu było więcej Żydów przed wojną?). Było, było. Część domów była ich, mieli swoje sklepy. Po wojnie musieli to wszystko zwinąć i wyjechać. Były nawet takie budynki, które wyleciały w powietrze, zostały zniszczone. Byli całkiem w porządku, i mieszkali tutaj, mieli przedsiębiorstwa, a biznes mieli taki, że potem musieli to wszystko zwinać i wyjechać. (A to większość z nich została zamordowana, czy wyjechała?). Część wyjechała, cześć zabili (18Cm).

Tendencja do mylenia faktów, zmieniania ich skali czy znaczenia pojawia się nie tylko w odniesieniu do mitycznej emigracji Żydów, dzięki której uniknęli oni jakoby w czasie wojny śmierci. Bywa, że respondenci błędnie identyfikują również sprawców Zagłady lub Zagłada nie istnieje dla nich jako wydarzenie unikatowe, roztapiając się w morzu innych nieszczęść. Przykładem tego jest wypowiedź cytowanej już wcześniej kobiety, która opowiadając o swojej babci, ukrywającej w czasie wojny Żydów, stwierdziła:

[Babcia] ukrywała Żydów, tak... Ale ja już nie wiem, czy przed Niemcami, czy przed władzą radziecką. Wydaje mi się, że i przed tymi, i przed tymi, bo władza radziecka też była przeciwko Żydom. Oni przecież też... To poszedł naród przeciwko narodowi (15Ck).

Czasami okazuje się też, że to, co w opinii rozmówców dotyczy Zagłady, w rzeczywistości odnosi się do zupełnie innego wydarzenia - jak w kolejnym cytacie, gdy rozmówczyni w odpowiedzi na pytanie o to, czy w Żółkwi ginęli podczas okupacji Żydzi, opisała wspominaną już wcześniej masakrę więźniów NKWD:

Tak, strasznie dużo [zginęło Żydów], jest taki pomnik, taki koło rady miejskiej stoi, że jak ludzie szli, to ich żywcem zakopywali, to nawet jak szli z cerkwi, to się ziemia jeszcze ruszała (19Bk).

Zagłada pamiętana przez tę respondentkę to Zagłada w zmienionych, nieprawdziwych faktograficznie ramach, ale w wymiarze moralnym w dalszym ciągu jest to pamięć Zagłady, nie zaś rzezi więźniów żółkiewskiego NKWD, natomiast dwie faktografie nakładają się na siebie w pamięci respondentki nieświadomie. Zdarza się jednak, że pamięć jednego wydarzenia jest dla świadka pretekstem do opowiedzenia o innym, które niepostrzeżenie przejmuje ramy opisowe pierwszego, niejako je zawłaszczając. Tak właśnie dzieje się w przytoczonej obecnie wypowiedzi: 
(A czy babcia opowiadała, że mordowali tu Żydów? Czy może w szkole pan słyszał?). W szkole mówili, że mordowali Żydów. Zawsze. Czy jakieś filmy historyczne widziałem, takie, gdzie zabijają Żydów. Palili ich strasznie, oglądałem, czasem oglądam takie filmu historyczne, że bardzo się nad nimi znęcali. W zasadzie to nad wszystkimi, można powiedzieć, nad Ukraińcami też się znęcali. Był Wielki Głód... (Ale Wielki Głód - to komuniści, a...). No, ja rozumiem. Ale mam na myśli, że tak samo, czy człowiek jest Żydem, czy Ukraińcem, to tak samo przeważnie słyszałem, że nad Żydami się znęcali. Tyle ludzi, tyle ludzi zabili $(20 \mathrm{Cm})$.

Opowieść o Zagładzie staje się tu okazją, by na zasadzie analogii wspomnieć o cierpieniu własnej grupy. Nieco podobny zabieg narracyjny - użycie ram opisowych cudzego tragicznego losu do opisu swojego własnego, np. przedstawienie warunków transportu deportowanych słowami, których z reguły używa się, mówiąc o transporcie do obozu koncentracyjnego - Harald Welzer (ze współautorami swojego tekstu) określa jako zamianę ram ${ }^{20}$. Podobnie jak rozmówcy Welzera, mój żółkiewski respondent nie neguje Holokaustu, ale - bardziej chyba świadomie niż ci ostatni - stara się podkreślić, że cierpienie jest uniwersalne, a jego własna grupa została doświadczona nie mniej niż Żydzi.

\section{Następne pokolenia: niepamięć}

Oprócz pamięci fragmentarycznej i gubiącej się w faktach wielokrotnie spotykałam się w grupie respondentów z młodszych pokoleń po prostu z brakiem pamięci: na 44 wywiady aż 10 osób albo nie wiedziało w ogóle o tym, że w Żółkwi mieszkali kiedyś Żydzi, albo o tym, w jaki sposób z niej zniknęli. Czasami wiązało się to z ogólnym brakiem zainteresowania przeszłością miasta, niezależnie od tego, z jaką konkretnie przeszłością - niepamięć była tu niewybiórcza, traktowała tak samo Żydów, Polaków i Ukraińców. Jedna z respondentek na moje pytanie, czy przed wojna było tak samo - tzn. czy mieszkańcami Żółkwi byli głównie Ukraińcy - odpowiedziała: „To ja już pani nie powiem, nie wiem. Nie bardzo w to wnikaliśmy” (21Bk). Z całego wywiadu z nią wynikało, że wszystko to, co stało się przed jej przyjazdem do Żółkwi w latach siedemdziesiątych, jest dla niej nieistotne, bo dotyczy nie tylko rzeczy dawno minionych, ale również „nie swoich” - w tym wypadku „nie swoi” byli dla niej zarówno żółkiewscy Żydzi i Polacy, jak i Ukraińcy. Czasami jednak niepamięć dotykała tylko grupy obcych - właśnie Żydów i Polaków, przy jednoczesnym żywym zainteresowaniu historią grupy własnej. Jak pisze znany ukraiński historyk Jarosław Hrycak, galicyjscy Ukraińcy wykształcili silną tożsamość narodową kosztem zapominania - nie tylko o tym, że będący ich bohaterami narodowymi Kozacy we Lwowie wsławili się przede wszystkim splądrowaniem greckokatolickiej

${ }^{20}$ Zob. Harald Welzer, Sabine Moller, Karoline Tschuggnall, „Dziadek nie byt nazista”. Narodowy socjalizm i Holokaust w pamięci rodzinnej [w:] Pamięć zbiorowa i kulturowa. Wspótczesna perspektywa niemiecka, red. Magdalena Saryusz-Wolska, Warszawa: Universitas, 2009. 
katedry św. Jura, lecz także o tym, że Galicję zamieszkiwali kiedyś liczni Inni (i jak skończyła się ich obecność tutaj) - Żydzi, Polacy, Niemcy. Wyrzucenie ich z pamięci było tym łatwiejsze, że większości z nich po wojnie zabrakło fizycznie ${ }^{21}$. Takie wyrzucenie z pamięci wydarzeń Zagłady wydaje się najbardziej wstrząsające, gdy dotyczy osób wykształconych, które poza tym jednym elementem żółkiewskiej historii wiedziały dużo o wielokulturowej historii swojego miasta:

(A zagłada Żydów? Czy o tym się gdziekolwiek mówiło? Z rdzennymi mieszkańcami, na przykład?). Nie wiem, niczego nie mogę powiedzieć. A co pani ma na myśli - Zagłada kiedy, w jakim okresie? (Podczas drugiej wojny światowej prawie wszyscy Żydzi zostali w Żółkwi wymordowani przez Niemców). O tym dowiedziałem się w zasadzie kiedy - w ostatnich latach. Ale nie, przepraszam, my mówimy chyba o różnych sprawach. To, co ja wiem, dotyczy zamordowanych przez enkawudzistów, których szczątki zostały ekshumowane. A o zamordowanych Żydach, szczerze mówiąc, nie wiem, i nawet... A co, jest w Żółkwi, powiedzmy, jakiś grób na cmentarzu? (Tak, na głównym cmentarzu jest). Znaczy się - minus po mojej stronie (22Bm).

Niepamięć o społeczności żydowskiej, szczególnie zaś milczenie panujące w tej kwestii w przestrzeni publicznej, jest sprawą zauważaną przez tych, którzy pamiętają. Są to przede wszystkim rozmówcy, dla których Zagłada z różnych względów stała się sprawą osobistą i ważną, czy to przez kontakty z ocalonymi, mieszkającymi przed wojną w ich domu i odwiedzającymi ich po $1991 \mathrm{r}$. (autorka pierwszej cytowanej dalej wypowiedzi), czy to przez odkrycie, że w ich domu ukrywali się w czasie wojny Żydzi (autor drugiej wypowiedzi). Bywa, że reakcje tych osób na publiczne milczenie są bardzo emocjonalne:

Córeczko, za mojej pamięci, za mojego pobytu tutaj, nikt, ani jedna świnia nie beknęła, że to jest żydowskie miasto, założone przez Żydów razem z... Oni potem, jak przyjechali... O tym, że postawili Trójcę [cerkiew św. Trójcy], postawili... Piotr I kazał tu coś robić na granicy, a hrabia Żółkiewski zaczął budować to miasto od cerkwi i od tych umocnień... Ale o Żydach ani widu, ani słychu. Dziecko, jakby ich tu nigdy nie było, jakby to nie oni. [...] Nikt mi o Żydach nic nie powiedział, i to jest dla mnie takie dziwne, nawet słowa „Żyd” nikt nie wypowiedział, takie to dla mnie dziwne. Może ja nie aż tak bardzo wnikam, dziecko, w te sprawy, ale gdyby mówili, słyszałabym, gdyby w gazecie, w telewizji, w wiadomościach - słyszałabym (23Bk).

A myśmy tu niczego nie wiedzieli, absolutnie, tu nikt się z tym nie afiszował, nikt tym... [...] No, że Żydzi, to mówili, to... Wie pani, takie czasy były. Wtedy dużo się nie mówiło o tym. Ale ja w zasadzie co nieco wiedziałem. Ten Lajner opowiadał mi, to był bardzo dobry taki kolega mój, i człowiek, to on czasami coś tam opowiadał... Jak uciekał, jak był tu w getcie, jak to wszystko... (16Bm).

${ }^{21}$ Yaroslav Hrytsak, Historical Memory and Regional Identity among Galicia's Ukrainians [w:] The Roots of Ukrainian Nationalism: Galicia as Ukrainian's Piedmont, red. Paul R. Magocsi, Toronto: University of Toronto Press, 2002. 
Drugi z respondentów wskazuje na przyczyny panującego w tej sprawie milczenia, wyjaśniając jednocześnie, skąd on sam dowiedział się o Zagładzie. Z jego słów jasno wynika, że w czasach sowieckich jedynym kanałem przekazywania wiedzy o historii Żydów były kontakty nieformalne. To przez prywatne rozmowy z nielicznymi osobami, które mieszkały w Żółkwi przed wojną, oraz, w tym konkretnym wypadku, przez świadectwo ocalonego, nowi mieszkańcy miasta i ich dzieci dowiadywali się o obecności w przeszłości Żydów w Żółkwi. Jeśli do takiej komunikacji nie dochodziło, pamięć nie była przekazywana; zastapić mogły ją co najwyżej informacje oficjalne, te jednak nie wchodziły bynajmniej w skład radzieckiej polityki historycznej. Jak trafnie zauważył Timothy Snyder, Żydzi wschodnioeuropejscy zostali przez powojenną kulturę pamięci ograbieni z pamięci, ponieważ symbolem Holokaustu stało się Auschwitz, nie zaś jedno z tysięcy bezimiennych miejsc, w których dokonywano eksterminacji Żydów w Europie Wschodniejej ${ }^{22}$ Nie mniej słuszne jest chyba jednak stwierdzenie, że z pamięci o Żydach ograbiono również ich przedwojennych sąsiadów, Ukraińców i innych mieszkańców Europy Wschodniej, przez kilkadziesiąt lat spychając pamięć Zagłady na margines radzieckich ofiar wojny $^{23}$. Aż do lat dziewięćdziesiątych w Żółkwi nie powstał żaden pomnik upamiętniający Zagładę, a żydowskie dziedzictwo materialne (synagoga, rzeźnia rytualna, cmentarz) popadało stopniowo w ruinę, przy czym trudno uznać, by działania takie jak budowa bazaru na dawnym kirkucie były przypadkowe; należy je raczej potraktować jako element całościowej strategii (nie)pamięci. W tym właśnie szerszym kontekście należy patrzeć na przytaczane w tej części mojego tekstu przykłady pamięci fragmentarycznej i niepełnej lub jej zupełnego braku. Ludzie, którzy dorastali w takiej sytuacji komunikacyjnej, odcięci byli od obu źródeł przekazu kształtujących zazwyczaj pamięć społeczną: wykorzenienie wykluczało lub ograniczało przekaz rodzinny, totalitarne państwo nie robiło zaś nic, by ten przekaz zastąpić. Po 1991 r. ukraińska polityka pamięci zaczęła się zmieniać, zmiany te są jednak powolne, a na poziomie lokalnym często mało zauważalne. Oprócz wspominanych już niedostatków w programie edukacji, które w żaden sposób nie są uzupełniane przez żółkiewskich nauczycieli, warto zwrócić uwagę na marginalność działań podejmowanych w dziedzinie upamiętniania Zagłady. Jeśli słuszne jest twierdzenie Stefana Rohdewalda, że zagłada wschodnioeuropejskich Żydów dokonała się na peryferiach - zarówno fizycznych, jak i symbolicznych - to na podobnych peryferiach znalazła się po 1991 r. uwolniona od sowieckiej zmowy milczenia pamięć o Zagładzie ${ }^{24}$. Powstałe w Żółkwi po upadku komunizmu pomniki upamiętniające Zagładę są społecznie niewidzialne; fizycznie - ponieważ najważniejszy z nich, zaniedbany i zdewastowany, stoi kilka kilometrów za miastem, pośrodku pustego pola, na którym w 1943 r. zamordowano kilka tysięcy żółkiewskich Żydów; ale również symbolicznie, ponieważ o istnieniu dwóch pozostałych (symboliczna mogiła

\footnotetext{
${ }^{22}$ Zob. Snyder, Holocaust: ignorowana rzeczywistość.

${ }^{23}$ Zob. Hrynewycz, Mit wijny...

${ }^{24}$ Zob. Rohdewald, Post-Soviet Remembrance of the Holocaust...
} 
na cmentarzu komunalnym oraz symboliczny ohel cadyka na bazarze, dawniej cmentarzu żydowskim) nie wie ogromna większość mieszkańców Żółkwi. Lokalne władze nie podejmują żadnych inicjatyw związanych z żydowskim dziedzictwem miasta, nie wspierają też starań podejmowanych przez organizacje społeczne, które w ukraińskich warunkach mają małe możliwości działania. Można więc zaryzykować twierdzenie, że przy pozornej otwartości na zmiany polityka pamięci w kontekście Zagłady bardzo niewiele zmieniła się w Żółkwi po 1991 r. Paradoksalnie, brak realnych działań przy ich pozornej akceptacji może być przez część mieszkańców odbierany jako sygnał mówiący o tym, jak nieistotny jest przedmiot niedoszłego upamiętniania ${ }^{25}$.

Wydaje się, że trudno też mówić o zmianach, jakie miałyby zachodzić w drugim kanale przekazu, czyli w pamięci rodzinnej. Podobnie jak w tej oficjalnej, temat Zagłady jest w pamięci rodzinnej nieobecny - respondenci, którzy twierdzili, że ich dziadkowie czy rodzice mówili im o Zagładzie w Żółkwi, należeli do wyjątków. W większości galicyjskich domów w dalszym ciągu nie rozmawia się o Holokauście; badania przeprowadzone wśród ukraińskich studentów przez ukraińską psycholog Jelenę Iwanową pokazują, że całość wiedzy o Zagładzie młodzi ludzie uzyskują w procesie edukacji (jeśli uzyskują ją w ogóle); w domu rodzinnym dowiadują się o Holokauście tylko ci, którzy sami mają żydowskie korzenie ${ }^{26}$. Biorąc pod uwagę jakość i ilość wiedzy o Zagładzie przekazywanej w szkole, trudno spodziewać się, że młodzi ludzie z Żółkwi będą poszukiwanymi przez Patricka Desbois pośrednimi świadkami Zagłady.

Swoistą przeciwwagę dla ogromu niepamięci stanowią w Żółkwi osoby, które aktywnie angażują się w upamiętnianie Zagłady. To dzięki nim (oraz inicjatywie jednego z dwojga pozostałych w mieście po wojnie ocalonych, którego nazwisko wielokrotnie padało w wypowiedziach respondentów - Zygmunta Lajnera) powstały w mieście wspomniane już pomniki. W latach dziewięćdziesiątych obecny wicedyrektor kompleksu muzealnego w żółkiewskim zamku założył organizację społeczną o nazwie „Switło kultury” (Światło kultury), która zajęła się restauracją żółkiewskich zabytków oraz podjęła starania mające na celu budowę kilku pomników - w tym pamięci zamordowanych Żydów. To od tego właśnie rozmówcy usłyszałam jedyne w trakcie tak wielu rozmów słowa otwartego potwierdzenia

${ }^{25}$ Warto zauważyć, że ani konkretnie w Żółkwi, ani ogólnie na Ukrainie nie występuje na razie zjawisko fascynacji historyczną kulturą żydowską. Podczas gdy w Polsce w wielu środowiskach, szczególnie wśród ludzi młodych, odkrywanie kultury polskich Żydów, chociażby w „etnograficznym” wymiarze muzyki czy kuchni, ale również zgłębianie dziejów wspólnot lokalnych, staje się sposobem na budowanie swojej własnej tożsamości regionalnej (pisze o tym między innymi Kaja Kaźmierska, analizując polską kulturę pamięci w książce Biografia i pamięć. Na przykładzie pokoleniowego doświadczenia ocalonych z Zagłady, Kraków: Nomos, 2008), na Ukrainie zjawisko to jest nieobecne na szerszą skalę.

${ }^{26}$ Zob. Jelena Iwanowa, Regionalnyje osobiennosti kolektiwnoj pamiati studientow o holokostie w sowriemiennoj Ukrainie, „Holokost i suczasnist’. Studiji w Ukrajini i switi” 2005, nr 2 (4). 
i potępienia ukraińskiego udziału w Zagładzie. Była to również jedna z niewielu osób, u których pojawiła się pogłębiona refleksja nad przyczynami i charakterem Zagłady.

To, co stało się z Żydami, to ja pani powiem, że ta zaraza nazizmu, ona panowała nie tylko w Niemczech, ona zaraziła całą Europę. Wie pani przecież, że i kraje słowiańskie, i na Bałkanach, i tak dalej, wszędzie, w tym - na Ukrainie. Wszędzie były dość silne wpływy, a tym bardziej ta propaganda, rozpętana przeciwko Żydom. No i były też być może jeszcze jakieś inne, obiektywne podstawy, bo czasami na przykład na Ukrainie dochodziło do takiego straszliwego wyzysku naszej ludności przez Żydów, były przypadki, gdy cerkwie były w arendzie u Żydów, oni mieli klucz i żeby się pomodlić, trzeba było zapłacić, i tym podobne, i zwyczajne lichwiarstwo, i tak dalej, no, sytuacja była bardzo... bardzo złożona. I stopniowo pod wpływem tej propagandy to tak w ludzi wnikało. Potem, gdy przyszły te czasy, gdy naziści realizowali swoją politykę, podlizywano się, dostosowywano tutaj do tego, bano się przeciwstawić oficjalnej władzy, oczywiście. A ci - bezbronni, prześladowani, i wszystko poszło... I ukraińska policja pomagała tu Niemcom z tym gettem, i z likwidacją tego getta. To są znane rzeczy. Jedni łapali i wydawali, a inni przechowywali i ratowali, takie sprawy. (pauza) Wszystkie narody mają w historii piękne stronice i takie, których trzeba się bezwzględnie wstydzić (24Bm).

Założona przez rozmówcę organizacja obecnie nie prowadzi już działalności, wydaje się jednak, że jest to konsekwencją nie tylko napotykanych przez nią niepowodzeń i wypalenia się pewnej idei ${ }^{27}$, lecz także zmiany pokoleniowej. Mimo iż w Żółkwi nie ma obecnie środowiska analogicznego do „Switła kultury”, znaleźć można osoby, dla których dziedzictwo żydowskie i pamięć Zagłady są ważnymi elementami tożsamości rodzinnego miasta. Ich zainteresowania wynikają najczęściej z wykształcenia lub wykonywanego zawodu; wśród moich rozmówców z tej kategorii było dwóch historyków (pracownik centrum informacji turystycznej oraz organizacji pozarządowej), historyk sztuki (dyrektorka muzeum) oraz etnolog (pracownica kompleksu muzealnego). Ta ostatnia w następujący sposób mówi o początkach swojej fascynacji historią Żydów żółkiewskich:

Wybrałam sobie temat związany z Żydami, jeszcze gdy studiowałam. Była u nas taka katedra - historia kultury narodu żydowskiego. A koło mnie mieszkał jeden, znaczy się, Żyd, miejscowy, w czasie wojny wywieziony z getta do obozu janowskiego, któremu udało się uciec. Czemuś nie chciał opowiedzieć, jak mu się to udało. Ale ja znalazłam jego relację w Żydowskim Instytucie Historycznym w Warszawie, taaak. (A kto to był?). Jego nazwisko Lajner. Potem dał tę książkę, on miał tę „Zagładę Żydów żółkiewskich”. Tak się w zasadzie zaczęło. Zaczęłam zajmować się tym tematem, ciekawiło

${ }^{27}$ Podjęta przez „Switło kultury” próba restauracji synagogi zakończyła się sporym skandalem. Organizacji udało się uzyskać dotację na remont dachu ze środków amerykańskich, materiały zakupione na potrzeby remontu (blacha miedziana) zostały jednak skradzione i odnalazły się w stanie wykluczającym już ich użycie w punkcie skupu metali kolorowych. 
mnie to. (A wcześniej wiedziała pani [o Zagładzie], czy po prostu wtedy dowiedziała się pani więcej?). Wiedziałam, bo babcia opowiadała mi o Żydach. [...] To znaczy o tym, że Żydzi mieszkali tu przed wojną, to wiedziałam. No, a jak przeczytałam tę książkę o zagładzie Żydów żółkiewskich, zrobiło to na mnie ogromne wrażenie. Pisałam już wtedy prace roczne, na początku nie o Holokauście, a ogółem o społeczności żydowskiej, siedemnasty wiek, osiemnasty, dziewiętnasty. A potem już pracę dyplomową napisałam o Holokauście, i magisterską też o Holokauście. To taka historia moich zainteresowań. No i tak podczas badań, to już jakiekolwiek informacje, które mi się o Żydach trafiały, zbierałam do mojej pracy (25Ck).

Warto w tym miejscu wyraźnie podkreślić, że takie postawy, jak cytowanych ostatnio respondentów, są w Żółkwi raczej wyjątkiem niż standardem, co potwierdza częściowo fakt, że rozmowy z wszystkimi osobami z tej kategorii nagrane zostały poza cyklem pokoleniowym - do każdej z nich trafiałam właśnie dlatego, że wiedziałam o jej zainteresowaniu tematyką żydowską. Istotne jest też to, że rozmówcy ci mają spore poczucie wyobcowania w swoim środowisku i, jak twierdzą, podejmowane przez nich próby popularyzacji wiedzy o społeczności żydowskiej w Żółkwi oraz jej Zagładzie spotykają się najczęściej albo z brakiem zainteresowania, albo z niezrozumieniem, również ze strony władz lokalnych.

\section{Epilog: nie nasza pamięć - cudze dziedzictwo?}

Jak można podsumować i jakie wnioski wyciągnąć z przeprowadzonej w artykule analizy? Zdecydowanie najczęściej pamiętają o Zagładzie przedstawiciele pierwszego pokolenia powojennych przesiedleńców, ci, którzy pojawili się w mieście tuż po tym, jak zniknęli z niego Żydzi. Wśród nich z kolei najwięcej wiedzą o tym osoby mieszkające przed wojną w pobliskich wsiach, a po 1945 r. przybyłe do Żółkwi w poszukiwaniu lepszego losu; to one jako jedyne widziały część zagłady Żydów żółkiewskich na własne oczy. O Zagładzie w Żółkwi obszerniej od innych opowiadali z reguły rozmówcy, którzy byli świadkami podobnych wydarzeń w swoich miejscowościach rodzinnych oraz osoby bardziej wykształcone. Najważniejszym czynnikiem wpływającym na jakość pamięci o Zagładzie wydaje się jednak utrzymywanie przez przesiedleńców dobrych kontaktów z rdzennymi mieszkańcami Żółkwi: ci, którzy po wojnie często rozmawiali o przeżyciach wojennych ze swoimi sąsiadami, zdecydowanie najczęściej umieli powiedzieć o Zagładzie w Żółkwi coś więcej. Natomiast grupą, w której pamięć Zagłady jest najmniejsza, czasami zaś nie ma jej wcale, są migranci z Ukrainy Wschodniej i innych republik ZSRR.

W pamięci następnych pokoleń dominuje przede wszystkim wiedza, którą można by określić jako książkowo-przewodnikową. Jeśli rozmówcy z tej grupy w ogóle wiedzą o Holokauście w Żółkwi cokolwiek oprócz tego, że się wydarzył (co samo w sobie jest już sporym „osiągnięciem”), wiedzę tę uzyskali ze źródeł oficjalnych, przede wszystkim w procesie edukacji, z telewizji czy książek. Ich rodzice i dziadkowie nie mówili im w domu o Zagładzie nawet wtedy, gdy sami o niej wiedzieli. W specyficznej sytuacji społecznego strachu i przemilczania oraz publicznej 
tabuizacji wielu wojennych tematów mieszkańcy powojennej Żółkwi zdobywali się czasem na niezbyt bezpieczne przekazywanie pamięci o losach własnej grupy (na przykład o przynależności do partyzantki niepodległościowej czy przesiedleniach), ale nie mówili już o losach Obcych. Z przekazu prywatnego, rodzinnego wiedzieli o Zagładzie tylko ci z moich rozmówców, których rodzice lub dziadkowie mieszkali przed wojną w okolicach Żółkwi, dlatego też Zagłada żółkiewskich Żydów wpisywała się częściowo w ich doświadczenie wojny. Nawet oni jednak poza dwoma wyjątkami (ratowanie Żydów przez chrześcijan) nie opowiadali o Zagładzie w sposób podmiotowy. Za tymi strzępkami pamięci rozciąga się ocean niewiedzy i nieświadomości, przy czym czasami granica między zwykłym brakiem zainteresowania i obojętnością na sprawy przeszłości a wyparciem z pamięci specyficznie kwestii Zagłady jest płynna. Co ważne, niepamięć jest niezależna od wykształcenia - w grupie osób, które nie znały losu żółkiewskich Żydów, znalazły się między innymi dwie nauczycielki i inżynier.

Podsumowaniem analizy problemu pamięci Zagłady w Żółkwi mogłyby być dwa cytaty z wywiadu z jednym z rozmówców - tym, który po wizycie w jego domu osób ocalonych odkrył dla siebie przeszłość rodzinnego miasta.

Widziałem, że ich to przejmowało, że to było dla nich bardzo... Oni tam płakali, mdleli, cucili ich tam... Mówię im, widzę, że to takie dla was ważne, to postawcie tu jakiś kamień... (Znak jakiś...). Tak... Możecie postawić jakiś znak czy coś takiego. No i tak pomyślałem, i na tym się skończyło. Jak to dla was takie... Jak chcecie, to zróbcie sobie. (A pan by nie miał nic przeciwko?). Skąd, absolutnie (16Bm).

Zrobili tu taki pomnik, jest tu taki, ten, Lajner. Tam, gdzie rozstrzeliwali Żydów za Żółkwią, zrobili pomnik. Jest tam taki lasek i tam on im postawił pomnik, taki, no, ja bym powiedział, całkiem-całkiem, za swoje pieniądze to wszystko. (Za swoje pieniądze? Ale prywatne czy żydowskiej...?). Nie, żydowskiej. Tam nawet napisane było, ja byłem koło tego pomnika. [...] Był pomnik i ta ich, jak się to nazywa... Taki żelazny łuk, bardzo taki... (Menora?). O tak, menora. I potem zaczęli go straszliwie niszczyć, to $z$ tej, to z tamtej strony. Były tam miedziane litery, taaak, „pamięci Żydów”, coś tam było napisane, i to zaczęli zrywać. [...] I tą menorę zabrał jego [Lajnera] syn, powiedział, że to najważniejsze, co w tym pomniku, tak to zrozumiałem. I nic tam już nie ma (16Bm).

Oba fragmenty pokazują, jak bardzo „nie nasza” jest pamięć Zagłady dla mieszkańców miasta, którzy osiedli w nim po 1945 r. Tablicę upamiętniającą Zagładę Żydzi mogą sobie ewentualnie postawić, właściciel domu nie będzie protestował; nie poczuwa się jednak w żaden sposób do tego, by zrobić to samemu. Pomnik pamięci ofiar Holokaustu został zbudowany z inicjatywy ostatniego żółkiewskiego Żyda i za pieniądze żydowskiej diaspory, a po jego zdewastowaniu zachowane elementy zabiera syn nieżyjącego już wówczas ocalonego. W tych hipotetycznych i rzeczywistych działaniach miejscowi są nieobecni (poza anonimowymi wandalami niszczącymi pomnik, raczej z powodu chęci zarobku niż „prawdziwego” antysemityzmu). 
Oczywiste jest, że żaden z moich rozmówców nie doświadczył Zagłady jako świadek - starsi przyjechali zbyt późno, młodsi zbyt późno się urodzili, dla nikogo z nich nie może to być elementem pamięci biograficznej. Niemniej pamięć społeczna danego zdarzenia bywa mniej lub bardziej osobista, emocjonalna, przeżywana i uznawana za „swoją”. Pamięć Zagłady wśród nowych mieszkańców Żółkwi wydaje się na tej skali pamięcią odległą, niedotykalną i niedoświadczoną, często pomijaną, aż do jej zupełnego braku. W przywołanej przeze mnie na początku klasyfikacji Rosy Lehmann wszyscy moi respondenci są obcymi; co więcej, najczęściej są obcymi, którzy słyszeli mało lub wcale, i nie mogą dalej o Zagładzie świadczyć. Obcość ta jest stopniowalna i ma różne wymiary: przestrzenny (pierwsze pokolenie migrantów, którzy w czasie dokonywania się Zagłady byli gdzie indziej), czasowy (drugie pokolenie migrantów, urodzonych po Zagładzie), ale także moralny - wtedy, gdy ofiary Zagłady wyłączane są ze wspólnoty uznawanej za własną.

Pytanie o przyczyny tego ogromu niewiedzy odsyła nas do sposobów kształtowania się pamięci społecznej, która powstaje jako efekt współdziałania różnych źródeł przekazu: oficjalnego (państwowego), prywatnego (przede wszystkim rodzinnego) i publicznego, ale niezwiązanego z polityką historyczną państwa. O tym, dlaczego w wypadku Zagłady w Żółkwi zabrakło i w dalszym ciągu brakuje przekazu rodzinnego, pisałam w artykule. Należałoby się jeszcze zastanowić, dlaczego tak ograniczony jest współcześnie (dziś) w Żółkwi przekaz oficjalny oraz dlaczego publiczny przekaz społeczny ma tak małe znaczenie. Odpowiedź na pierwsze pytanie, choć wykracza poza zadania, jakie sobie postawiłam w tym tekście, jest dość prosta: Zagłada nie była i nie jest priorytetem w ukraińskiej polityce historycznej po 1991 r. Wprawdzie temat ten nie jest zakazany, jak w czasach ZSRR, ale oficjalna historiografia w zasadzie go ignoruje, a to ona przede wszystkim kształtuje dyskurs edukacyjny $^{28}$. Jak pisze Anatolij Podolśkyj, dyrektor Ukraińskiego Centrum Badań nad Holokaustem, winy za taki stan rzeczy nie można już dzisiaj zrzucać na sowieckie dziedzictwo, choć w pewnym sensie ukraińska polityka historyczna jest kontynuatorką sowieckiej: przemilcza Holokaust, by nie pomniejszać „naszych” ofiar - Ukraińców, którzy zginęli w czasie wojny, Wielkiego Głodu czy innych represji sowieckich $^{29}$. Strategia ta dotyczy zresztą nie tylko Zagłady, podobnie niewygodnym tematem są na przykład antypolskie akcje UPA w czasie wojny i późniejsze wysiedlenia ludności polskiej. Zarówno w polityce historycznej państwa ukraińskiego, jak i w ukraińskim dyskursie publicznym nie ma dziś miejsca na Zagładę, ponieważ obie te przestrzenie zajęte są przez upamiętnianie własnych ofiar i własnych bohaterów, tak samo jak Zagłada przemilczanych w ZSRR. To, że państwo nie inicjuje

${ }^{28}$ Oczywiście na Ukrainie toczą się ważne dyskusje dotyczące Zagłady (warto tu wymienić polemikę Jarosława Hrycaka i Sofiji Hraczowej o udziale Ukraińców w Holokauście czy też ostatnią gorącą debatę wokół książki Omera Bartova Erased: Vanishing Traces of Jewish Galicia in Present-day Ukraine, zob. s. 546-552), ale w odróżnieniu na przykład od polskiej dyskusji wokół książek Jana Tomasza Grossa nie wychodzą one poza wąskie środowiska zainteresowanych tematem intelektualistów.

${ }^{29}$ Zob. Podolśkyj, Ukrajinśke suspilstwo i pamjat' pro holokost... 
i nie wspiera działań mających na celu upamiętnianie Zagłady, nie wykluczałoby jednak aktywności społecznej w tej sferze - wystarczy spojrzeć na nieformalne, inicjowane społecznie akcje przywracające w przestrzeni publicznej pamięć o ukraińskim podziemiu niepodległościowym, które w latach dziewięćdziesiątych nie było jeszcze bynajmniej przez ukraińskie władze uznawane za godne upamiętniania. Społecznego upamiętniania Zagłady prawie nie ma, ponieważ prywatna i społeczna pamięć Zagłady została w okresie sowieckim skutecznie zmarginalizowana i niemal zupełnie zniszczona, dzieląc los zniszczonych społeczności lokalnych Galicji. Wyraźnie widać to na przykładzie Żółkwi, gdzie najpierw zniknęła istniejąca przed wojną ludność - Żydzi, Polacy, Ukraińcy - potem zaś pamięć o tych, których zabrakło zupełnie. To, co możliwe i potrzebne jest dzisiaj, to nie tyle przywrócenie pamięci, ile jej mozolne zbudowanie niemal zupełnie od nowa. Wydaje mi się jednak, że dopóki nie stanie się to częścią ukraińskiej strategii pamięci na szczeblu państwowym, trudno oczekiwać szybkich rezultatów.

\section{Indeks rozmówców}

1Ak Polka, ur. 1928 w Łodzi, jej ojciec - Ukrainiec - w 1945 r. wyjechał na Ukrainę. Pracownica mleczarni. Zamężna z miejscowym Ukraińcem.

2Ak Ukrainka, ur. 1927 w zamożnej rodzinie chłopskiej niedaleko Żółkwi. Od 1945 r. łączniczka UPA. W 1950 r. wywieziona z całą rodziną na Syberię. Wróciła do Żółkwi w 1962 r. Pracowała w fabryce. Zamężna z Ukraińcem spod Żółkwi.

3Am Ukrainiec, ur. 1934 we wsi w powiecie złoczowskim w biednej rodzinie chłopskiej. Skończył szkołę milicyjną, od 1958 r. pracował jako śledczy, potem jako naczelnik wydziału śledczego Żółkwi. Żonaty z Ukrainką pochodzącą ze Wschodu.

4Ak Ukrainka, ur. 1929 we wsi niedaleko Żółkwi. Do Żółkwi przyjechała w 1951 r. do pracy jako nauczycielka. Zamężna z Ukraińcem pochodzącym ze Wschodu.

5Ak Ukrainka, ur. 1928 we wsi niedaleko Tomaszowa Lubelskiego. W 1944 r. przesiedlona wraz z rodziną do obwodu dniepropietrowskiego, w 1946 r. próbując wrócić do domu, znalazła się w Żółkwi. Wyszła za mąż za Rosjanina, oficera Armii Czerwonej. Pracowała w drukarni.

6Am Ukrainiec, ur. 1930 we wsi koło Tomaszowa Lubelskiego. W 1946 r. jego rodzina dobrowolnie wyjechała na Ukrainę sowiecką. Po kilku miesiącach pobytu pod Bereżanami osiadła w Żółkwi. Pracował w administracji i w służbie bezpieczeństwa. Żonaty z Ukrainką spod Żółkwi.

7Am Ukrainiec, ur. 1925 we wsi koło Tomaszowa Lubelskiego. W 1944 r. jego rodzina dobrowolnie wyjechała do Dniepropietrowska. W 1946 r. próbowała wrócić do domu, ostatecznie osiadła w Żółkwi. Pracował fizycznie.

8Ak Rosjanka, ur. 1918 we wsi w obwodzie kurskim. Skończyła liceum pedagogiczne. Wyszła za mąż za pracownika rejonowego komitetu partii. W czasie wojny mąż zginął na froncie, a ją ewakuowano do Kirgizji. Zapisała się na ochotnika do Armii Czerwonej, doszła do Berlina. Po demobilizacji skierowano ją do pracy w rejonowym komitecie partii w Krakowcu, a potem w Żółkwi. Zamężna z Rosjaninem. 
9Ak Rosjanka, ur. 1923 w obwodzie krasnodarskim. Jej rodzice i rodzeństwo zmarli w czasie Wielkiego Głodu. Po wojnie skierowana została do pracy do szpitala polowego w okolicach Żółkwi. W 1947 r. przeprowadziła się do Żółkwi, pracowała w szpitalu. Zamężna z Ukraińcem z Żytomierszczyny.

10Ak Ukrainka, ur. 1927 we wsi w obwodzie połtawskim. Jej rodzice zginęli podczas represji stalinowskich w latach trzydziestych i czterdziestych, ona sama wychowywała się w sierocińcu. Skończyła liceum pedagogiczne, w 1948 r. wyszła za mąż za rosyjskiego inżyniera, który dostał skierowanie do pracy w Żółkwi. Pracowała jako nauczycielka.

11Ak Ukrainka, ur. 1923 we wsi w obwodzie kijowskim. W czasie wojny przebywała na robotach w Niemczech oraz w obozie koncentracyjnym. W latach 19461948 pracowała jako nauczycielka na Tarnopolszczyźnie, w 1950 r. wyszła za mąż za oficera radzieckiego (Ukraińca z jej rodzinnej wioski) i przeprowadziła się z nim do Żółkwi. Pracowała w szkole.

12Bm Ukrainiec, ur. 1942 we wsi w powiecie chełmskim. W 1946 r. jego rodzina została wysiedlona do Dniepropietrowska. W 1947 r. osiedliła się w Żółkwi. Pracował w łączności jako elektryk.

13Bk Ukrainka, ur. 1963 w Żółkwi. Córka respondentki 2Ak. Wykształcenie zawodowe, obecnie bezrobotna.

14Ck Ukrainka, ur. 1981 w Żółkwi. Jej dziadkowie pochodzili ze Lwowa, po wojnie zostali wysiedleni na Syberię. Skończyła kulturoznawstwo we Lwowie, studiowała w Kanadzie. Pracuje w wydziale turystyki rady miejskiej we Lwowie. Założyła wraz z mężem organizację społeczną, której celem jest kulturalny i turystyczny rozwój miasta.

15Ck Ukrainka, ur. 1978 w Żółkwi. Jej dziadkowie pochodzą spod Żółkwi. Studiowała ekonomię na uniwersytecie we Lwowie. Obecnie nie pracuje zawodowo, zajmuje się dziećmi.

16Bm Ukrainiec, ur. 1956. Jego rodzice byli Rosjanami - ojciec był milicjantem, matka pochodziła $\mathrm{z}$ rodziny represjonowanej w latach trzydziestych, po wojnie uciekła do Galicji przed głodem. On sam pracował jako milicjant.

17Bk Ukrainka, ur. 1966 w Żółkwi. Jej rodzice pochodzą spod Tomaszowa Lubelskiego, trafili do Żółkwi jako przesiedleńcy w latach 1944-1946. Wykształcenie średnie. Prowadzi własną działalność gospodarczą.

18Cm Ukrainiec, ur. 1973 w Żółkwi. Jego matka została przesiedlona do Żółkwi z okolic Lubaczowa w 1946 r., ojciec pochodzi z Żółkwi. Wykształcenie średnie, pracuje w firmie prywatnej.

19Bk Ukrainka, ur. 1944 we wsi koło Sanoka. W 1944 r. jej rodzina została przesiedlona do Żółkwi. Pracuje jako bibliotekarka.

20Cm Ukrainiec, ur. 1984 w Żółkwi. W 1945 r. jego dziadkowie pochodzący spod Lubaczowa wyjechali do Żółkwi. Pracuje jako nauczyciel wychowania fizycznego.

21Bk Ukrainka, ur. 1954 we wsi koło Złoczowa. Na początku lat siedemdziesiątych przyjechała do Żółkwi do pracy. Pracowała w drukarni. Synowa respondentki $1 \mathrm{Ak}$. 
22Bm Ukrainiec, ur. 1949 w Żółkwi. Skończył ekonomię na uniwersytecie we Lwowie, obecnie na emeryturze, mieszka we Lwowie.

23Bk Ukrainka, ur. 1955 w Żółkwi. Córka respondentki 5Ak. Skończyła historię na uniwersytecie we Lwowie. Przez 15 lat pracowała w policji w Krzywym Rogu. Obecnie zajmuje się medycyną niekonwencjonalną.

24Bm Ukrainiec, ur. 1955 we wsi niedaleko Żółkwi. Absolwent Politechniki Lwowskiej, inżynier. W 1977 r. przyjechał do Żółkwi do pracy. W 1990 r. założył organizację społeczną „Switło kultury”, która inicjowała remont wielu żółkiewskich zabytków oraz budowę pomnika upamiętniającego Zagładę Żydów. Obecnie wicedyrektor kompleksu muzealnego.

25Ck Ukrainka, ur. 1973 w Żółkwi. Jej dziadkowie pochodzili ze wsi niedaleko od Żółkwi oraz z Wołynia. Pracuje w kompleksie muzealnym, pisze pracę doktorską o zagładzie Żydów żółkiewskich.

\title{
Słowa kluczowe
}

Zagłada na Kresach Wschodnich II RP, pamięć Zagłady, pamięć społeczna, stosunki polsko-żydowskie, stosunki ukraińsko-żydowskie

\begin{abstract}
The article discusses Holocaust memory in Ukrainian Galicia (using the example of Żółkiew near Lvov). Qualitative research - biographical and in-depth interviews - allowed for an analysis of that memory on various levels and in relation to such factors as: official Soviet memory, family accounts, sovereign Ukraine' historical policy and the Jewish Diaspora's initiatives to commemorate the Holocaust. The analysis revealed the existence of highly varied memory groups, whose major determinants are: family's origins and its lot during the war as well as the respondent's age group.
\end{abstract}

\section{Key words}

Holocaust in the Polish Eastern Borderlands, Holocaust remembrance, social memory, Polish-Jewish relations, Polish-Ukrainian relations 